\title{
LAW ENFORCEMENT ON THE INHERITANCE OF SIRI MARRIED IN THE JUDICIAL VERDICT
}

\author{
Rusli $^{1}$ \\ Graduate student at State University of Gorontalo (UNG) \\ Email: arrasuly_03@yahoo.co.id,
}

\author{
Nur Mohamad Kasim ${ }^{2}$ \\ Lecturer at State University of Gorontalo (UNG) \\ Email: nurkasim@ung.ac.id
}

\section{Duke Arie Widagdo ${ }^{3}$}

Lecturer at State University of Gorontalo (UNG)

Email: dukearie@gmail.com

\begin{abstract}
Siri marriage is an interesting issue to be discussed in various perspectives. The legal consequences of unmarried marriage need clarity, especially in terms of inheritance rights. The law Number 1 of 1974 concerning marriage has required that marriages be recorded, as a form of legality recognized by the State. But on the other hand, the Marriage Law has provided absolute freedom to get married in accordance with the provisions of their respective religions. In various legal products, through law enforcement in the judiciary, it creates many perspectives, resulting in multiple interpretations in the position of the right of inheritance in siri marriage. This research, more specifically, examines law enforcement against siri marriage by examining judicial verdicts. The research approach focuses more on normative law by focusing on the study of legal norms, in producing new arguments, theories or concepts. The research data were collected through a library review and legal opinion. The findings of this study indicate that law enforcement of the inheritance rights of siri marriage gets a portion of the inheritance by substantially considering the aspects of justice. Judicial decisions consider aspects of legal benefit to the rights arising from unmarried marriage. The implication of this finding is that the marriage law is urgent to be amended, the occurrence of multiple interpretations of legal marriage becomes a gap in the implementation of unregistered marriage.

Perkawinan siri menjadi isu hangat untuk diperbincangkan dalam berbagai perspektif. Konsekuensi hukum dari kawin siri perlu mendapatkan kejelasan khususnya dalam hak warisnya. UU No. 1 Tahun 1974 tentang perkawinan telah
\end{abstract}


mengaharuskan perkawinan dicatat, sebagai bentuk keabsahan nikah yang diakui Negara. Namun disisi lain, dalam UU perkawinan telah memberikan kebebasan secara mutlak untuk melangsungkan nikah sesuai dengan ketetapan agama masingmasing. Dalam berbagai prodak hukum, melalui penegakan hukum di peradilan melahirkan banyak perspektif, sehingga menimbulkan multitafsir dalam kedudukan hak waris kawin siri. Penelitian ini lebih spesifik lagi mengkaji penegakan hukum terhadap kawin siri dengan menelaah putusan peradilan. Pendekatan penelitian lebih mengetengahkan hukum normatif dengan memfokuskan kajian pada norma hukum, dalam menghasilkan argumentasi, teori atau konsep baru. Data penelitian dikumpulkan melalui telaah pustakan dan pendapat hukum. Temuan penelitian ini menunjukkan bahwa penegakan hukum hak waris kawin siri mendapatkan porsi waris dengan mempertimbangan aspek keadilan secara subtantib. Putusan peradilan mempertimbangkan aspek kemanfaatan hukum terhadap hak yang timbul atas kawin siri. Implikasi temuan ini bahwa UU perkawinan urgen untuk di amandeman, terjadinya multitafsir terhadap nikah sah menjadi celah dalam pelaksanaan kawin siri.

Keywords: Law Enforcement; Siri Marriage; Judge's Verdicts.

\section{INTRODUCTION}

Marriage is a method used by humans to form a community in a social structure, namely the family. The family is a special structure, with each other in the family having ties whether by blood or marriage. This makes a difference in the marriage of other living creatures, marriage is an agreement (judicial), made in the form of a contract because it is a legal event, not a biological event or a mere instinctive demand for sexual relations between a man and a woman.

In the event of a marriage, legal norms and rules of order are required that have been regulated in such a way as to maintain the continuity of the marriage relationship, to fulfill mutual rights and obligations. Marriage is a human need that is part of the law, clearly described in Article 28B Paragraph (1) of the 1945 Constitution $^{1}$, that everyone has the right to form a family and continue their descendant through a legal marriage.

The basic foundation of marriage according to Law Number 1 of 1974 concerning Marriage. Marriage is a physical and mental bond between a man and a woman as husband and wife with the aim of forming a happy and eternal family

${ }^{1}$ The state has formulated Law Number 1 of 1974 concerning Marriage as a form of state guarantee to protect every citizen, and does not want discriminatory treatment, the purpose of Article 28H Paragraph (2) of the 1945 Constitution, namely that every person has the right to obtain convenience and special treatment to obtain equal opportunities and benefits in order to achieve equality and justice. 
(household) based on the principle of Belief in the one and only God. ${ }^{2}$ The law Number 1 of 1974 is a judicial effort to make changes and reforms to marriage patterns in society which have many negative effects. ${ }^{3}$ It breaks the freezing pattern of marriage with discriminatory values against women's rights and positions. One of the principles or principles stated in the Marriage Law is the principle of equality between wife and husband. ${ }^{4}$

The right in marriage is a legal right, defined as an interest protected by law, or a desire recognized by law, so there was no legal right before the existence of the law. So there is no legal right without being regulated in a regulation. ${ }^{5}$ Inheritance rights must be based on the legality of the marriage, in the Law on Article 2 Paragraph (2) the registration of marriage becomes the validity of the marriage. Although their position is disputed, it functions as a legal condition of marriage or an administrative requirement. When viewed from a political and legal perspective, it is understood as the administration of marriage that must be obeyed by citizens. ${ }^{6}$ The legality polemic raises a dichotomy between legal under religious law and legal under state law. The conditions for the validity of a marriage depend on two factors, namely, first it is carried out according to religious law, secondly it is recorded according to the applicable laws. ${ }^{7}$

The Constitutional Court in Decision Number 46/PUU-VIII/2010, the judicial review is explained by citing the General Explanation number 4 letter (b) of Law Number 1 of 1974, assessing that marriage registration in Article 2 Paragraph (2) is an administrative requirement of marriage its position is the same as the recording of important events in a person's life, for example a birth, death which is stated in certificates, a certificate which is also included in the registration list. This means that if a marriage event does not comply with the administrative requirements of the marriage procedure, the state considers that the marriage event does not meet the formal requirements as a legal action. ${ }^{8}$ This ruling weakens the requirements for registration of marriages which stipulate that Marriage Registration Officers through the Religious Affairs Office (KUA) for the Muslims,

\footnotetext{
${ }^{2}$ Direktorat Jenderal Badan Peradilan Agama Mahkamah Agung Republik Indonesia: Himpunan Peraturan Perundang-Undangan di Lingkungan Peradilan Agama Tahun 2014, p. 338.

${ }^{3}$ Sayuruddin Dauly, Pencatatan Perkawinan Dalam Persfektif Hukum Islam dan Pollitik Nasional, (Tinjauan Normatif terhadap Mahkamah Konstitusi Nomor 46/PUU-VIII/2010) (IKAHI: Majalah Hukum Varia Peradilan, Year XXXI Number 369 August 2016), p. 101.

${ }^{4}$ Mukhtar Zamzami, Perempuan dan Keadilan dalam Hukum Kewarisan Indonesia (First Ed. Jakarta: Kencana, 2013), p. 303.

${ }^{5}$ Jimly Assiddiqie and M. Ali Safa'at, Teori Hans Kelsen tentang Hukum (5 ${ }^{\text {th }}$ Ed.; Jakarta: Konstitusi Press, 2018), p. 65.

${ }^{6}$ Sayuruddin Dauly, Pencatatan Perkawinan dalam Persfektif Hukum Islam, p. 102.

${ }^{7}$ Munir Fuady, Konsep Hukum Perdata (Jakarta: Raja Grafindo Persada, 2014), p. 10.

${ }^{8}$ Sayuruddin Dauly, Pencatatan Perkawinan dalam Persfektif Hukum Islam, p. 109.
} 
and the Civil Registry Office for non-Muslims. ${ }^{9}$ A popular term of marriage that is not recorded from various models of mention such as unregistered marriage, siri marriage (nikah siri).

Meanwhile, the Court to this day still has different opinions regarding the formal judicial marriage, when faced with a case of disputes over the inheritance of a siri marriage. In this case, judges as law enforcers, at the first level Court, the Court of Appeal (judex facti), and the Court of Cassation (Supreme Court) as the judex juriz, these differences actually create legal problems for justice seekers. Judges' reasoning in solving legal problems in inheritance cases related to unregistered marriage is often divided due to differences in sources and the concept of thinking in compiling the legal construction. As a result, there is no legal structure that can guarantee the certainty of legal transactions in society. Therefore, in making legal decisions, judges are still very much influenced by subjective choices in fulfilling justice.

\section{DISCUSSION}

\section{A. The Nature and Cause of Inheritance}

The concept of inheritance, in the language of warits comes from the word waritsa which means the transfer of property from one party to another. The term syara', which is called warits, is the transfer of ownership from a deceased person to a living person. The Arabic term for inheritance law is called faraid, which in the literature of legal science there is no uniformity of terms used and while there are several terms such as inheritance law, inheritance law, inheritance law, inheritance law, mawaris law, and others. However, from a linguistic perspective, the appropriate term for the mention of "faraid law" is "inheritance law", which is also used in Law Number 7 of 1989 in conjunction with Law Number 3 of 2006 in conjunction with Law Number 50 of 2009 and the Compilation of Islamic Law (KHI). ${ }^{10}$

Inheritance is the impact of a person's death that causes transfer of rights and obligations. The transfer was aimed at the relatives he left behind, then it was called the term warasah, namely the heir. ${ }^{11}$ The difference in terms of inheritance in Islamic legal literature, the various terms are found with variants of the terms Islamic inheritance law, figh mawaris, faraid science and inheritance law. The term

${ }^{9}$ Faiq Tobroni, Penafsiran Hukum Dekonstruksi untuk pelanggaran Poligami (Komisi Yudisial Republik Indonesia: Jurnal Yudisial Vol. 9. Number 3 December 2016), p. 292.

${ }^{10}$ Rachmadi Usman, Hukum Kewarisan Islam dalam Dimensi Kompilasi Hukum Islam. Bandung: CV Mandar Maju, 2009), p. 3.

${ }^{11}$ Rahman I, Doi, Penjelasan Lengkap Hukum-hukum Allah (Syariah) (Jakarta: Raja Grafindo Persada, 2002), p. 352. 
has the same meaning, namely a form of transfer of inheritance. The difference is in the scope of discussion and the substance of a study. ${ }^{12}$ The transfer of assets while the inheritor is still alive is not considered as inheritance. ${ }^{13}$ This proves that death is a cause of inheritance, so without death there is no such thing as inheritance.

Theoretically, Muslims must share their inheritance according to Islamic law, and if there is a dispute it must be carried out before the Religious Court. ${ }^{14}$ The concept of the cause of inheritance in Islamic law is explained in the leading figh books, explained the causes of inheritance include the death of the person who inherits, ${ }^{15}$ the life of the heir after the person who inherited died, and there was no barrier preventing inheritance. ${ }^{16}$ Prof. Hasby As-Shiddiqi gave the definition of inheritance law (figh mawaris), namely the knowledge by which the heirs can know, those who cannot inherit, the amount received by each heir and the method of return. ${ }^{17}$

The provisions of the inheritance law in the KHI are regulated in book three, starting from Article 171 to Article 193. In the KHI regulates the heir, which explains the nature of the heir, is prevented from obtaining inheritance, the group of heirs, the rights of heirs and the obligations of the heirs to the heirs. Furthermore, the provisions in the KHI regulate the share of heirs in lineage and marital relationships. In addition, the KHI also explains the inheritance provisions of children outside of marriage, who can only inherit from each other with their mother and their mother's family.

In the Compilation of Islamic Law, book three on inheritance in Article 192 and Article 193 has regulated the provisions for the distribution of dzawil furud heirs. This article is more technically regulated in inheritance distribution by considering the division number and the numerator in the distribution of dzawil furud inheritance. It can be seen that the KHI has adequate inheritance provisions that have regulated the determination of heirs and their technicalities. Despite Presidential Instruction Number 1 of 1991 regarding KHI is not strong enough to

\footnotetext{
${ }^{12}$ Mohammad Muhibbin and Abdul Wahid, Hukum Kewarisan Islam (Sebagai Prmbaharuan Hukum Positif di Indonesia (Jakarta: Sinar Grafika, 2009), p. 5.

${ }^{13}$ Ahmad Azhar Basyir, Hukum Waris Islam (14 $4^{\text {th }}$ Ed.; Yogyakarta: UII Press Yogyakarta, 2001), p. 132.

${ }^{14}$ Pagar, Himpunan Peraturan Perundang-undangan di Indonesia (First Ed.; Medan: Perdana Publishing, 2010), p. 117.

${ }^{15}$ Sayyid Sabiq, Fiqh Sunnah Jilid 5 (5 ${ }^{\text {th }}$ Ed.; Jakarta: Pena Pundi Aksara, 2013), p. 512.

${ }^{16}$ Sayyid Sabiq, Fiqh Sunnah Jilid 5, p. 241.

${ }^{17}$ Teungku Muhammad Hasbi As-Shiddiqi, Fiqih Mawaris (Semarang: Pustaka Rizki Putra, 2001), p. 5.
} 
bind law enforcement in the Religious Court because its position is not yet included as positive law. So that its position is only as an unwritten material law.

The inheritance law is the law that regulates the transfer of assets left by a person who dies and the consequences for his heirs. Article 830 of the Civil Code states, "inheritance only takes place because of death". ${ }^{18}$ The rules in the Civil Code are clearly understood that inheritance can only occur because of the cause of death. In the Civil Code, inheritance is regulated in Book II of the Civil Code. There are 300 articles regulating inheritance in the Civil Code. Regulations Article that regulates it can be found in Article 830 to Article 1130 of the Civil Code.

The inheritance law is a law that regulates the transfer of assets left by someone who dies and the consequences for the heirs. ${ }^{19}$ The provisions in Article 830 regarding the cause of inheritance due to death, so that the death of the inheritor has opened the transfer of his/her property. In the transfer of assets, it is regulated in Article 836 of the Civil Code that they can inherit each other if the heirs are still alive. Thus, in the Civil Code does not give inheritance rights to heirs who have died earlier than the heirs.

Referring to Article 830 of the Civil Code shows that inheritance can occur because of death or an inheritor has died. The absolute element is called an inheritor because of its position as a cause of inheritance (death) and abandonment of property, because the inheritor cannot address it if it does not leave wealth. ${ }^{20}$

Article 830 stipulates that death is the cause of inheritance, the death of the inheritor in this case can be divided into (1) the death of the inheritor is truly known (intrinsic death), that is, it can be proven by the five senses that he/she is really dead; and (2) to die for the sake of the law, was declared by the Court, namely: it is not really known according to the fact which can be proved that he/she is dead.

In addition, the provisions of life in Article 836 of the Civil Code are a reason to become heirs and obtain inheritance. The provisions of life in the Civil Code explain that; (1) real life, that is, according to the fact he is really still alive, it can be proven by the five senses; (2) legally alive, that is, he is not known in fact to be alive. In this case, including the baby in the mother's womb. ${ }^{21}$ So the proof for obtaining an inheritance right is the life of the heir, real life and legally living.

${ }^{18}$ Effendi Purangin, Hukum Waris (Jakarta: PT Raja Grafindo Persada, 2013), p. 3.

${ }^{19}$ Effendi Purangin, Hukum Waris (Jakarta: Raja Grafindo Persada, 1997). p. 3.

${ }^{20}$ Anasitus Amanat, Membagi warisan Berdasarkan Article-Article Hukum Perdata BW (Jakarta: PT Raja Grafindo Persada, 2001), p. 6.

${ }^{21}$ Civil Code (KUHPerdata) Article 1 Paragraph 2 


\section{B. The Inheritance Rights of Siri Marriage}

The reason for someone entitled to inheritance is the existence of marital relations, kinship, freeing slaves. While the barrier to inheritance, one of which is the difference in religion between inheritor and heir, which can invalidate a person's right to inherit an inheritance. Barriers to inheritance are actions or things that can invalidate a person's right to inherit the inheritance after there are reasons to inherit. ${ }^{22}$ The inheritance right of the siri marriage is considered urgent to show inheritance rights in various laws and regulations and other regulations that govern inheritance rights in general. Rights in this case are those who are entitled to inherit property (heirs).

In particular regarding inheritance, it is regulated in Presidential Instruction No.1 of 1991 concerning Compilation of Islamic Law (KHI) in Article 171 that inheritance law is a law that regulates the transfer of ownership rights to inheritance (tirkah), determines who is entitled to become heirs. and how many parts each. ${ }^{23}$ The provisions in the distribution of inheritance rights need to be explored in relation to the inheritance rights for unregistered marriages.

The provision that obtains inheritance rights in the KHI is found in Article 174 concerning groups of heirs according to blood relations and according to marital relations consisting of: widowers or widows. And if all the heirs are there, only children, fathers, mothers, widows or widowers are entitled to inherit. ${ }^{24}$ In Article 174 above, that the group of heirs is included in relation to the marriage relationship. The mention of marriage is still general without mentioning the type of marriage. So that it can still be interpreted in general about the form of inheritance with marital relations, including siri marriage. The inheritance right of a siri marriage or a siri marriage relationship is not mentioned as an heir who is prevented from obtaining inheritance. This can be seen in Article 172 which requires religion (Islam) to be mutually inheriting from the Muslim inheritors. ${ }^{25}$

Article 172 makes religion one of the conditions for mutual inheritance in Islamic inheritance law. Therefore, heirs of apostasy cannot become heirs for an inheritor who is Muslim, as stipulated in this regulation, unless it has been pursued by other means, such as wajibah wills. In Article 173 in relation to the failure to inherit from each other because the judge's verdict is blamed and slanders the heir, ${ }^{26}$ then the heirs are prevented from inheriting.

\footnotetext{
${ }^{22}$ Ahmad Azhar Bazhar Basyir, Hukum Waris Islam (Yogyakarta: Universitas Islam Indonesia, 1990), p. 16.

${ }^{23}$ Compilation of Islamic Law (KHI) Article 171.

${ }^{24}$ Compilation of Islamic Law (KHI) Article 174.

${ }^{25}$ Compilation of Islamic Law (KHI) Article 172.

${ }^{26}$ Compilation of Islamic Law (KHI) Article 173.
} 
In Article 173 there is no mention of the prohibition of marital relations, in the context of siri marriage to not obtain inheritance rights. However, Article 186 states the inheritance rights of children outside of marriage, which directly provides a line of validity for a marriage because of the clause of children who are not entitled to inheritance rights. Article $186 \mathrm{KHI}$ states that children born outside of marriage only have an inherited relationship with their mother and their mother's family. ${ }^{27}$

Article 186 again provides an explanation that is opaque, because what is mentioned is a child outside of marriage. The provisions referred to as children outside of marriage are adultery or unregistered marriage (siri). However, after paying attention to various articles in the KHI in relation to the provisions of marriage, it has provided many reliefs in marriage issues. This means that the KHI provides convenience in marriage, it can be found in Article 53 in conjunction with Article 99 which provides convenience for pregnant women outside of marriage to marry and the position of legal children as children born as a result of legal marriage.

Article 53 of $\mathrm{KHI}$ indicates that marriage can take place when a woman is pregnant with a man who impregnates her. Even the marriage has been considered as having permanent legal force, because without having to remarry after the child is born. Furthermore, in Article 99 KHI the provisions regarding legal child, who are child born as a result of a legal marriage. This is very mitigating because even within hours of the age of marriage and the child resulting from adultery is born, the child is categorized as a legal child.

For this reason, the provisions in Article 186 are the result of recognition of marriage. This means that children outside of marriage only have inheritance rights to the mother and their mother's family. Hence, the child cannot inherit the father's right. The consequences were given as a result of not having a legal marriage. Meanwhile, the regulations have made it easier for the marriage to be legal.

The key to this convenience is none other than just expecting a registered marriage, this is clear in Articles 4, 5 and 6 of the KHI which are in line with Article 2 Paragraph 2 of Law Number 1 of 1974 concerning marriage. In Article 4 which requires legal marriage, which is carried out according to Islamic law in accordance with Article 2 paragraph (1) of Law Number 1 of 1974 concerning Marriage. ${ }^{28}$ Article 5 requires that it be registered by a Marriage Registration Officer

\footnotetext{
${ }^{27}$ Compilation of Islamic Law (KHI) Article 186.

${ }^{28}$ Compilation of Islamic Law (KHI) Article 4.
} 
(PPN) for the sake of benefit. ${ }^{29}$ And Article 6 which requires that a marriage must be carried out before and under the supervision of a Marriage Registration Officer in order to obtain legal force. ${ }^{30}$

So, in Article 186 what is meant as a child outside of marriage is a child who is illegitimate according to Law Number 1 Year 1974 jo KHI. Such illegitimate children are categorized as children whose results of siri or unregistered marriage. For that in the KHI jo Law Number 1 of 1974 concerning marriage does not recognize the legality of siri marriage and the inheritance rights of siri marriage (siri wife and children). Therefore, unregistered marriages do not have inheritance rights as in KHI which is based on Article 2 Paragraph 2 of Law Number 1 of 1974 concerning Marriage.

Then the inheritance rights in the Civil Code, which are inheritance in the Civil Code, have identified the groups that can become heirs. Article 832 mentions people who are entitled to be heirs, which are (1) Group I: families that are in a straight line downward, namely the husband or wife who is left behind, children, and descendant along with husband or wife who live longer; (2) Group II: families that are in a straight line up, such as parents and siblings and their descendant; (3) Group III: consisting of grandparents, grandparents, and ancestors; (4) Group IV: family members who are on the line to the side and other families up to the sixth degree. $^{31}$

The category of heirs stipulated in the Civil Code shows who the heirs take precedence based on the order. Group II heirs cannot inherit the inheritor's inheritance if the class I heirs still exist. So in the Civil Code, the heirs take precedence over the order of their respective groups.

To narrow down the study, the inheritance rights of both the wife and children resulting from a siri marriage. The principle of inheritance in the Civil Code, Article 832 states that mutual inheritance is due to blood relations and the exception is due to marital relations (husband and wife). The two of them are still together as husband and wife and are not divorced. This condition is an absolute requirement in the Civil Code to become an heir. In this Article, it does not appear that there is any mention of the marriage relationship which is carried out in series.

The stipulation in the Civil Code regarding the heirs (erfgenaam) or all people entitled to inheritance, ${ }^{32}$ it is found that Article clauses have legalized the inheritance of marriage which is not based on law. Article 832 of the Civil Code explains that what is meant by heirs are members of a legitimate blood family

\footnotetext{
${ }^{29}$ Compilation of Islamic Law (KHI) Article 5.

${ }^{30}$ Compilation of Islamic Law (KHI) Article 6.

${ }^{31}$ Civil Code (KUHPerdata) Article 832.

${ }^{32}$ Anasitus Amanat, Membagi Warisan Berdasarkan Article-Article Hukum Perdata BW, p. 6.
} 
according to the law and outside of marriage as well as husband and wife who live outside of marriage and husband and wife who live the longest. ${ }^{33}$ It is clear that siri marriages can be accommodated in Article 832 of the Civil Code to obtain inheritance rights.

It is unclear whether the heirs that are categorized as extramarital relations are children resulting from unmarried marriages or adulterous children born without marital ties. However, it can be further analyzed in Article 832 of the Civil Code, legalizing children outside of marriage to obtain inheritance. Article 862 in conjunction with Articles 280, 281 of the Civil Code which describes inheritance or inheritance and it turns out that leaving the child out of wedlock, is entitled to receive it as long as it is recognized.

Articles 862, 280 and 281 explain that if the deceased leaves the children out of wedlock legally recognized according to law, the inheritance is divided in the manner specified in the following articles. ${ }^{34}$ With recognition of the child outside of marriage, a civil relationship is born between the child and the father or mother. ${ }^{35}$ Recognition of children outside of marriage can be done with an authentic deed. ${ }^{36}$

Based on this article, it is clear that in the Civil Code recognizes the existence of children outside of marriage to obtain inheritance from the inheritor as long as it has been legally recognized according to law. Even though children resulting from siri marriages, whose marriages have been carried out in a religious manner but in the context of siri (unregistered), can get inheritance rights if based on the Civil Code. However, in the position of a wife as a siri wife, it is not explained in detail in the Civil Code in terms of recognition as is the recognition of children out of wedlock. The term unregistered marriage (siri marriage; contemporary) is not known in the Civil Code, which only exists in the Civil Code, namely the nature of the deed, namely authentic deed and underhand deed. ${ }^{37}$

In this regard, marriages that are carried out in siri or under the hand, which are not officially recorded at the competent authority, the agreement is categorized as an underhand agreement which only binds both. In the Civil Code, there are two requirements to become an heir, including; First, heirs who are

\footnotetext{
${ }^{33}$ Civil Code (KUHPerdata) Article 832.

${ }^{34}$ Civil Code (KUHPerdata) Article 862.

${ }^{35}$ Civil Code (KUHPerdata) Article 280.

${ }^{36}$ Civil Code (KUHPerdata) Article 281.

${ }^{37}$ Authentic deed is a deed (letter) which is formally drawn up in front of or by an authorized public official at the place where the certificate is made in accordance with the provisions of the applicable laws (Article 1868 of Civil Code), b. Onderhands acte is a deed which is not made by or without the intermediary of a public official, but is made and signed by the parties who enter into the agreement or by an official who is not authorized to do so.
} 
determined by law, namely people who are entitled to receive an inheritance, as determined in the prevailing laws and regulations. This heir is regulated in (Article 832 of the Civil Code) according to the law the right to be heirs are blood relatives, both legal and out of wedlock, husband or wife who has lived the longest.

Second, an heir according to a will is an heir who receives an inheritance because of the presence of a testament from inheritor to heir which is written in a will. ${ }^{38}$ In Article 875 of the Civil Code, it is explained that a will (testamen) is a deed which contains a statement by a person about what he wants to happen after he dies, and is therefore revoked.

Therefore, in the Civil Code in relation to the inheritance rights of siri marriages, it is not explained in detail the mention of siri marriage. However, the Civil Code states the rights of children out of wedlock, who can be categorized as children resulting from siri marriages who receive inheritance rights or have the status of heirs. In addition, the Civil Code also regulates the transfer of inheritance by means of a will, so that there is an opportunity in a siri marriage to be assigned inheritance rights through will. For that, it is clear that the differences in Law Number 1 of 1974 concerning Marriage in conjunction with KHI which specifically regulates Islamic inheritance, which does not at all recognize the position of siri marriages in terms of inheritance rights, it is based on the invalidity of the marriage which results in the inheritance rights.

\section{The Inheritance Rights of a Siri Marriage in the Court Verdict}

Judges' verdicts are a form of law enforcement in line with the ideals of the law. The teaching of legal ideals (idée des recht) states that there are three elements of legal ideals that must exist proportionally, namely legal certainty (rechtssicherket), justice (gerechtikeit) and benefit (zweckmasigkeit). If it is related to the theory of law enforcement as conveyed by Gustav Radbruch in idée des recht, that is, law enforcement must fulfill these three principles. ${ }^{39}$

The status of the inheritance rights of a siri marriage entered a new phase with the issuance of the Constitutional Court (MK) Verdict Number: 46/PUU. VIII/2010. Regarding the application of dangdut singer Aisyah (Machica) Mochtar and her son M. Iqbal Ramadhan in a material review ${ }^{40}$ (judicial review) upon article

\footnotetext{
${ }^{38}$ Salim HS, Pengantar Hukum Perdata Tertulis (BW) (Jakarta: Sinar Grafika, 2002), p. 142.
}

${ }^{39}$ Fence M. Wantu, Antinomi dalam Penegakan Hukum Oleh Hakim. Jurnal Berkala Mimbar Hukum. Vol 19 Number 3 October, Yogyakarta: Faculty of Law Gadjah Mada University, 2007), p. 388 .

${ }^{40}$ In accordance with the authority possessed by the Constitutional Court, namely examining laws by law, the legal bases used are derived from the 1945 Constitution. The Constitutional Court $(\mathrm{MK})$ is a high state institution in the Indonesian constitutional system that 
2 Paragraph (2) concerning the registration of marriage and Article 43 Paragraph (1) of Law Number 1 Year 1974 concerning the position of children, have invited comments and public discussion.

Machica Mochtar considers that he has experienced and felt that her constitutional rights have been impaired by the Marriage Law, especially in relation to Article 2 Paragraph (2) and Article 43 Paragraph (1). This article actually creates legal uncertainty which results in losses for Machica Mochtar in relation to the marital status (siri) and the legal status of her child resulting from marriage.

Taking into account the Constitutional Court Verdict Number 46/PUU. $\mathrm{VIII} / 2010$, there are two legal substances in relation to unregistered marriage. Article 2 Paragraph (2) explains the registration of marriage, so that the output is recognition or legalization of an unregistered marriage (siri). In Article 43 Paragraph (1) which explains the position of the child resulting from an unregistered marriage (siri). The second implication of the inheritance rights of a siri marriage in the Constitutional Court decision, namely the inheritance rights to his siri wive and child resulting from his siri marriage.

The Constitutional Court Verdict Number 46/PUU-VIII/2010 which is a strong basis for the inheritance right of a siri marriage. In the Constitutional Court's verdict, the Constitutional Court judges made the legal basis for their verdict by taking into account the objectives of law enforcement, including certainty, justice and benefit.

Investigating Article 2 Paragraph (2) of Law Number 1 of 1974 which was submitted for judicial review of the Constitutional Court stated that Law Number 1 of 1974 in Article 2 Paragraph 2 requires registration of marriage. This is considered significant in preventing siri marriages and protecting women's rights and children's rights from the outcome of marriage. In addition to preventing irresponsible marriages. The treatise is in line with the provisions for child protection stipulated in the 1945 Constitution Article 28B paragraph (2) and 28D Paragraph (1).

Marriage registration in Article 2 Paragraph (2) of Law Number 1 of 1974 concerning Marriage is part of the role and function of the State in providing guarantees for the protection, advancement and fulfillment of Human Rights which must be carried out in accordance with the principles of a democratic state regulated in the 1945 Constitution Article 28I Paragraph (4) and Paragraph (5). The registration of marriage according to the Constitutional Court does not

holds joint judicial powers. -same as the Supreme Court (MA). As a constitutional organ, the Constitutional Court is designed to be the guardian and interpreter of the 1945 Constitution of the Republic of Indonesia through its verdicts. See, Ni'matul Huda, Teori dan Hukum Konstitusi ( $3^{\text {rd }}$ Ed.; Jakarta: Raja Grafindo Persada, 2003), p. 222. 
contradict constitutional provisions because restrictions are stipulated by law and carried out with the sole purpose of ensuring recognition and respect for the rights and freedoms of others, and to fulfill fair demands in accordance with moral considerations, religious values, security and public order in a democratic society in accordance with the 1945 Constitution Article 28J Paragraph (2).

The Constitutional Court stated that Law Number 1 of 1974 concerning Marriage Article 2 Paragraph (2) concerning the registration of a marriage is an administrative obligation, it does not determine whether a marriage is legal. This recording is intended so that it can be proven with perfect evidence, namely by authentic deeds in accordance with Law Number 1 of 1974 concerning Marriage Article 55. Basically, the determining factor whether a marriage is legal is that it fulfills the marriage requirements as regulated in Law Number 1 of 1974 concerning Marriage Article 2 Paragraph (1).

The explanation in the Constitutional Court verdict is clear that the Constitutional Court in its verdict rejects the judicial review of Law Number 1 of 1974 concerning Marriage Article 2 Paragraph (2). The Constitutional Court considers that marriage registration is in line with the provisions stipulated by the 1945 Constitution, so that marriages must be registered. However, in the next explanation, the Constitutional Court again stated that the validity of marriage did not lie in whether it was recorded or not, but the validity of marriage was determined by the legal conditions of marriage in accordance with Article 2 Paragraph (1), which was carried out in accordance with the provisions of religion.

Even though the Constitutional Court's verdict did not legalize Macica Mukhtar's marriage, it gave a green light to the validity of her marriage which was carried out in a series based on the legality based on her religion. This means that the decision of the Constitutional Court in considering the existence of Article 2 Paragraph (2) of Law Number 1 of 1974, that legal marriage registration means an administrative requirement for marriage, does not determine the legality of a marriage. The purpose of registering is for the benefit, where with this registration, the marriage will have a definite legal force. ${ }^{41}$

The position of the child resulting from a siri marriage basically still comes from the relationship between a boy and a girl, so that the Constitutional Court deems it unfair if the child only has a relationship with a woman as the mother, and the law exempts a man who causes the child's pregnancy and birth from responsibility. replied a father and at the same time, the law negated the rights of

${ }^{41}$ Yulia, Dampak Putusan Mahkamah Konstitusi No. 46 PUU-VIII/2010 Tentang Keabsahan Status Anak di Luar Nikah Perspektif Hukum Perdata Islam (Jurnal Al-Bayyinah Vol. VII Number 1. IAIN Bone, 2017), p. 66. 
the child to the man as the father. The development of technology is able to prove that a child resulting from a siri marriage is the child of a certain man. So the Constitutional Court states that a child born from a siri marriages have a civil relationship with their mother and their mother's family as well as with men as their father, which can be proven based on science and technology and/or other evidence that according to law has blood relations including civil relations with the family of the father.

The addition of Article 43 Paragraph (1) made by the Constitutional Court through its verdict Number 46/PUU-VIII/2010 is not limited to protection rights but has a very broad meaning as well as the meaning attached to legitimate children. In general, the various meanings in Article 43 of Law Number 1 of 1974 are the use of the term "civil relations". Because so far the meaning of a civil relationship includes the legal relationship, rights and obligations between the child and the father and mother, which can be in the form of: (1) lineage relationship; (2) mahram relationship; (3) the relationship between rights and obligations; (4) inheritance relationship (mutual inheritance) which is a continuation of the relationship of rights and obligations because of the lineage when they were both alive; and (5) guardianship relationship between father and daughter. ${ }^{42}$ The legal implication of the Constitutional Court's verdict in terms of the civil rights of siri marriage has received recognition in terms of rights. Because eliminating the relationship with a man that can be proven through science and technology and/or other evidence, it turns out to have a blood relationship as his father.

Regarding the Court's verdict regarding the rights of children outside of marriage, the Supreme Court (MA) emphasized that this right is not called inheritance. This is based on the opinion of the Hanafiah School, the term is not inheritance, but to provide for all children's living expenses according to their biological father's ability and propriety.

The main point in SEMA Number 7 of 2012 which is stated in the special description of the Result Formulation of the Plenary Meeting of the Religious Chamber of the Supreme Court of the Republic of Indonesia in this discussion is that children as the result of a siri marriage (siri children). Post Constitutional Court Verdict Number 46/PUU-VIII/2010 are children born in a siri marriage but have not been registered as recommended by the Marriage Law. In relation to Islamic law, the child is the same as a legal child, because the siri marriage is a legal marriage. So that the inheritance is the same as the legitimate children in general. Although the right is not called an inheritance, it is more an obligatory will.

\footnotetext{
${ }^{42}$ Yulia, Dampak Putusan Mahkamah Konstitusi No. 46 PUU-VIII/2010, p. 67.
} 
When studied according to Rawls' theory, which prioritizes the greatest equal freedom for all people (the greatest equal principle), ${ }^{43}$ then the Constitutional Court Verdict Number 46/PUU-VII/2010 has given freedom for everyone, whoever he is, to know his origins. It is unfair to sacrifice the rights of one or more persons with the status of a siri wife (unregistered) because this is contrary to justice which requires the principle of equal freedom for all people. When referring to Dworkin's theory, then for the wife in a position of discomfort over the choice to become a siri wife in a condition where she is faced with a difficult choice, and/or the child is born as the result of a siri marriage, it is a brute luck ${ }^{44}$ because this condition occurs not because of a comfortable choice of life, therefore appropriate compensation is given to the siri wife.

As for the inheritor (husband) of a siri or vice versa, the condition where having a siri wife/husband is a result of his own choice of life. According to Dworkin, the concept of justice must be sensitive to the possibility of a person's responsibility that occurs as a result of his own choice of life. In the case of a siri marriage, it is not an easy life choice, because the responsibility that is developed is the same as that of marriage in general (registered), so that it fulfills the concept of justice to consider how hard/long is a happy life in a household and services in its choice with the risk of social sanctions for a siri/unregistered marriage.

It should be remembered that fairness does not always mean equal treatment. This is in accordance with the principle put forward by Aristotle, that "the same is treated equally, and those who are not the same are also treated proportionally unequally." Rawls also allows differences, as long as these differences provide the greatest benefit to all people, especially those who are less fortunate (the different principle). In the different principle, Rawls admits that all people cannot demand the same benefits (equal benefits), but rather reciprocal benefits (reciprocal/mutual benefit). ${ }^{45}$

The principles of justice can be seen, as understanding between people and not exploiting for themselves as well as their contingency advantage. However, it is to regulate accidents of natural distribution and social opportunities, in a way that is mutually beneficial to all parties. So, in principle, it can be understood as justice while still considering the parties. ${ }^{46}$ Included in the consequences of the Constitutional Court decision with the benefits of the parties involved in it.

\footnotetext{
${ }^{43}$ John Rawls, A Theory of Justice Revised Edition (The Belknap Press of Harvard University Press, 1999), p. 53.

${ }^{44}$ Ronald Dworkin, Sovereign Virtue, The Theory And Practice Of Equality. Harvard University Press, 2000), p. 73.

${ }^{45}$ John Rawls, John Rawls, A Theory of Justice, p. 88.

${ }^{46}$ Joh Rawls, Distributive justice: Some addenda. In Natural Law Forum (Vol. 13, Number 1, Oxford University Press, 1968), p. 71.
} 
Dworkin added Rawls's opinion, that differences in treatment are possible as a consequence of one's life choices. ${ }^{47}$ In this case, of course it is impossible for a legal wife (registered) and a legal wife (unregistered/siri) to get the same rights. Justice basically aims to give everyone what is their right. In accordance with the principle of distributive justice which gives each person a proportionate share, it is only fitting that the share of inheritance rights and financing received by a siri wife is different from the children and the wife (registered). So, it is fair to give the right to a siri wife not an inheritance right but rather a compulsory will. As a right proportionally, namely $1 / 3$ part of the inheritance property, as part of a legacy, not as an heir. This consequence can be considered valid in the Constitutional Court decision, but it has no legal force because it is not registered with the Marriage Registration Officer (PPN).

Justice refers to truth and legitimacy, reasonableness and even serenity. Justice allows for a generous approach to self-care. Justice is where self-interest and the greater good reinforce one another. ${ }^{48}$ Hence, the Constitutional Court's decision which has provided several legal considerations is a form of justice that is legitimate and takes into account the consequences that arise in marriage. Paying attention to the continuity of the consequences arising from the marriage and the negative consequences for the party, so that taking into account the greater benefit becomes the basis of justice in the Constitutional Court decision.

\section{CONCLUSION}

The right and position of inheritance in siri marriage have been recognized in the Constitutional Court Verdict Number 46/PUU-VII/2012. The provisions in the Constitutional Court Verdict do not invalidate Article 2 Paragraph (2) of the Company Law, but in their explanation that the registration in Article 2 is not a requirement for the validity of marriage, but the validity of the conditions set by religion. The interconnection of the judge's decision has been issued by SEMA Number 7 of 2012, which philosophically provides inheritance rights in the form of a will. In the frame of justice it is considered to have provided justice in the inheritance right of siri marriage with a legal certainty. In addition, it fulfills a sense of legalist, procedural, commutative, indicative and professional justice. Taking sides of judges' verdict in law enforcement is a form of justice in the sense of law that provides certainty, justice and benefits. The legal status of siri marriage in the judicial decision does not have a clear position, but it has provided a portion of the

\footnotetext{
${ }^{47}$ Ronald Dworkin. Sovereign Virtue, The Theory And Practice, p. 73.
}

${ }^{48}$ Jocob Voorthuis and Cyrille Gijbels, A Fair Accord: Cradle to Cradle as a Design Theory

Measured against John Rawls' Theory of Justice and Immanuel Kant's Categorical Imperative. Sustainability, 2(1), 2010), p. 375-376. 
inheritance as a result of siri marriage. Judges' legal considerations in granting inheritance portions in unmarried marriages are more on the principles of legal benefit and justice on the basis of benefit.

\section{REFERENCES}

Amanat, Anasitus. Membagi warisan Berdasarkan Pasal-Pasal Hukum Perdata BW. Jakarta: PT Raja Grafindo Persada, 2001.

Assiddiqie, Jimly and M. Ali Safa'at. Teori Hans Kelsen tentang Hukum. $5^{\text {th }}$ Ed.; Jakarta: Konstitusi Press, 2018.

Basyir, Ahmad Azhar. Hukum Waris Islam. 14 ${ }^{\text {th }}$ Ed.; Yogyakarta: UII Press Yogyakarta, 2001.

Hukum Waris Islam. Yogyakarta: Universitas Islam Indonesia, 1990.

Civil Code (KUHPerdata)

Constitution of the Republic of Indonesia 1945

Doi, Rahman I. Penjelasan Lengkap Hukum-hukum Allah (Syariah. Jakarta: Raja Grafindo Persada, 2002.

Direktorat Jenderal Badan Peradilan Agama Mahkamah Agung Republik Indonesia: Himpunan Peraturan Perundang-Undangan di Lingkungan Peradilan AgamaTahun 2014.

Dauly, Sayuruddin. Pencatatan Perkawinan Dalam Persfektif Hukum Islam dan Pollitik Nasional, (Tinjauan Normatif terhadap Mahkamah Konstitusi Nomor 46/PUU. VIII/2010). IKAHI: Majalah Hukum Varia Peradilan, Tahun XXXI Number 369 Agustus 2016.

Dworkin, Ronald. Sovereign Virtue, The Theory And Practice Of Equality. Harvard University Press, 2000.

Fuady, Munir. Konsep Hukum Perdata. Jakarta: Raja Grafindo Persada, 2014.

Huda, Ni'matul. Teori dan Hukum Konstitusi. Third Ed.; Jakarta: Raja Grafindo Persada, 2003.

Law Number 1 of 1974 concerning Marriage

Muhibbin, Mohammad dan Abdul Wahid. Hukum Kewarisan Islam (Sebagai Prmbaharuan Hukum Positif di Indonesia. Jakarta: Sinar Grafika, 2009. 
Pagar. Himpunan Peraturan Perundang-undangan di Indonesia. Cet. I; Medan: Perdana Publishing, 2010.

Perangin, Effendi. Hukum Waris. Jakarta: PT Raja Grafindo Persada, 2013.

Hukum Waris. Jakarta: Raja Grafindo Persada, 1997.

Presidential Instruction Number 1 of 1991 concerning Compilation of Islamic Law (KHI).

Rawls, John. A Theory Of Justice Revised Edition. The Belknap Press Of Harvard University Press, 1999.

Rawls, Joh. Distributive justice: Some addenda. In Natural Law Forum. Vol. 13, Number 1, Oxford University Press, 1968.

Sabiq, Sayyid. Fiqh Sunnah Jilid 5. Fifth Ed.; Jakarta: Pena Pundi Aksara, 2013.

As-Shiddiqi, Teungku Muhammad Hasbi. Fiqih Mawaris. Semarang: Pustaka Rizki Putra, 2001.

Salim HS. Pengantar Hukum Perdata Tertulis (BW). Jakarta: Sinar Grafika, 2002.

Tobroni, Faiq. Penafsiran Hukum Dekonstruksi untuk pelanggaran Poligami. Komisi

Usman, Rachmadi. Hukum Kewarisan Islam dalam Dimensi Kompilasi Hukum Islam. Bandung: CV Mandar Maju, 2009.

Voorthuis, Jocob and Cyrille Gijbels. A Fair Accord: Cradle to Cradle as a Design Theory Measured against John Rawls' Theory of Justice and Immanuel Kant's Categorical Imperative. Sustainability, 2(1), 2010.

Wantu, Fence M. Antinomi dalam Penegakan Hukum Oleh Hakim. Jurnal Berkala Mimbar Hukum. Vol. 19 Number 3 October, Yogyakarta: Faculty of Law Gajah Mada University, 2007.

Yudisial Republik Indonesia: Jurnal Yudisial Vol. 9. Number 3 December 2016.

Yulia. Dampak Putusan Mahkamah Konstitusi Number 46 PUU-VIII/2010 Tentang Keabsahan Status Anak di Luar Nikah Perspektif Hukum Perdata Islam. Jurnal Al-Bayyinah Vol. VII Number 1. IAIN Bone, 2017.

Zamzami, Mukhtar. Perempuan dan Keadilan Dalam Hukum Kewarisan Indonesia. First Ed., Jakarta: Kencana, 2013. 